\title{
The effect of foreign direct investment on economic growth in Ghana: the role of exchange rate volatility
}

\author{
Samuel Antwi ${ }^{1}$, Prince Yeboah Boateng ${ }^{1}$ and Awudu Salley ${ }^{1}$
}

\begin{abstract}
The main objective of the study is to examine the effect of foreign direct investment inflows on economic growth in Ghana: the moderating role of exchange rate volatility. The study used Auto-Regressive Distributed Lags (ARDL) and Generalized Autoregressive Conditional Heteroskedasticity (GARCH). The study was based mainly on secondary data from World Development Indicators (WDI) where annual time-series data of 39 years was used for the study ranging from 1980 to 2018 . The study found that FDI had a positively significant impact on growth in the short run. Also, exchange rate volatility had a negatively significant impact on economic growth in the long run. However, domestic capital and trade openness had a positive significant impact on economic growth in the long run. The long-run estimate suggests that FDI decrease growth and exchange rate volatility dampen the negative effect of FDI on growth. The study, therefore, recommended, among other things, that the government should formulate policies that attract foreign direct investors into the country, as this may stabilize the economy.
\end{abstract}

JEL classification numbers: $047, \mathrm{G} 1$

Keywords: FDI, Economic growth, Exchange rate volatility, Ghana

\section{Introduction}

Governments strive to attract Foreign Direct Investment (FDI) because of the benefit of the FDI. The benefits include the stimulation of economic growth, trade improvement and employment opportunities. (Evans, Kesse, Gladys, \& Nyamoto, 2018; Antwi, Mills, Mills, \& Zhao, 2013). In over the years Ghana has used extensively, tax and non-tax incentives to woo foreign investors to the country. (Obeng, 2014). The non-tax incentives are grants, loans, investment subsidies, and rebates to enhance the competitiveness of businesses. The tax incentives take the form of the tax holiday, reduction in corporate income tax, removal of import tax, and the provision of low tax rates in export processing zones (Obeng, 2014). Presently, the Ghana government policy of "one district, one factory" has become a significant catalyst for FDI inflows into the country.

Studies such as Nketsiah and Quaidoo (2017), Adams and Opoku (2015), Nyarko et al. (2011) Mmieh and Owusu-Frimpong (2004), Antwi et al. (2013), Evans et al. (2018) had attempted to identify the effect of FDI on economic growth whereas Aliyu (2010), Alagidede and Ibrahim, (2017), Ullah et al., (2012), Wijeweera, Villano and Dollery (2010), Kyereboah-Coleman and Agyire-Tettey (2008), Kiliçarslan (2018), looked at the effect of exchange rate volatility on economic growth. The aforementioned studies failed to look at the moderating role of exchange rate volatility on the FDI-growth nexus. In the light of the above, the main objective of the study is to examine the the moderating role of on exchange rate

\footnotetext{
${ }^{1}$ Department of Accounting, University of Professional Studies, Accra, Ghana.
} 
volatility on FDI- economic growth nexus. This study hypothesised that, exchange rate volatility moderate the effect of FDI on economic growth in Ghana.

The rest of the paper is organized as follows. Section two contains literature review, while the methodology is dicussed in section three. The results and discussions are in section four. Conclusion and recommendtions for policy implementation are in section five.

\section{Literature Review}

\subsection{FDI and Economic Growth}

Raj and Pahwa (2018) in their paper "the impact of foreign direct investment on the economic growth of India" analyzed the causal relationship between foreign direct investment and economic growth in India. Using the cointegration approach for the period, 1990-91 to 2010-11. The result based on the Ordinary Least Square Method suggests that there is a positive relationship between foreign direct investment and gross domestic product and vice versa. This supports the findings from Sokang (2018) who looked at the topic "the impact of Foreign Direct Investment on economic growth in Cambodia" Time series data was used, and data was collected from 2006 to 2016. The correlation matrix and multiple regression analysis approaches were used to analyze the data. The study found that foreign direct investment has a positive impact on the economic growth of Cambodia.

\subsection{Exchange Rate Volatility and Economic Growth}

Agri et al. (2018) examine the effect of exchange rate policy and its volatility on economic growth. A dynamic distributed-lag model on time series data was used for the study. It is a causal dynamic economic model that shows the long-run and short-run relationship as the variables are restrictedly estimated, using secondary data. The study found a negative relationship between exchange rate volatility and economic growth. Alagidede and Ibrahim (2017) investigated the causes and effects of exchange rate volatility on economic growth in Ghana. The results found that while shocks to the exchange rate are mean reverting, misalignments tend to correct very sluggishly, with painful consequences in the short run as economic agents recalibrate their consumption and investment choices. About three-quarters of shocks to the real exchange rate are self-driven, and the remaining one quarter was attributed to factors such as government expenditure, money supply growth, terms of trade and output shocks.

\section{Data and Methodology}

\subsection{Data Collection Method}

Data on FDI, nominal exchange rate, secondary school enrolment, inflation, and economic growth were collected from World Development Indicator (WDI) over 39 years from the period of 1980 to 2018 because of the availability of data.

\subsection{Data Analysis and Techniques}

The data were analyzed with Stata 15 and Microsoft excel 2019. Autoregressive Distributed Lag (ARDL) was used to analyze the impact of FDI on economic growth: the moderating role of exchange rate volatility whereas GARCH was used to capture conditional volatility. Unit root was tested using Augmented Dickey-Fuller (ADF) and Phillips-Perron (PP) test at a 5\% level of significance.

\subsection{Description of Variables}

The inclusion of variables was largely informed by both theoretical and empirical literature. These include variables that were best known to have an impact on economic growth (Antwi \& Koranteng, 2017; Alagidede \& Ibrahim, 2017; Appiah-Konadu, Shitsi, Abokyi, \& Twerefou, 2016). All the data on 
the variables were extracted from WDI. The dependent variable is economic growth which was measured with Gross Domestic Product (GDP, \% annual growth)

Table 3.1: Description of Explanatory Variables

\begin{tabular}{lll}
\hline \hline Variable & Measurement & Expected Sign \\
\hline \hline 1.Growth $h_{t-1}$ & Lag of Growth & The reason to include the lag of the GDP variable is to \\
& & investigate the long- term effect of GDP. This is because it is \\
& expected that previous GDP will induce current economic \\
& growth $(+)$ (Fambon,2013)
\end{tabular}

2.Exchange Rate Using GARCH Volatility (VOL)

3.FDI

4.Trade

Openness (TO)

Total trade $(\%$ GDP)

5.Inflation (INF) Consumer Price Index

FDI inflows (\% GDP)
6.Capital (Cap)

Index

Exchange rate volatility puts an investor in a dilemma. Most investors do not like to invest in countries with high volatility (Aliyu, 2010). Therefore, a negative coefficient is expected (-)

It is the investment used to obtain a controlling interest (at least $10 \%$ stake) in a business operating outside the investor's home economy. FDI serves as a complement to domestic investment which is woefully inadequate to bring about economic growth in the host country. It is believed to bring about the transfer of technology as well as reduces poverty in the home economy, there is the need to attract FDI. This means FDI will impacts growth (Antwi et al., 2013). FDI is measured by FDI net inflows as a ratio of GDP is used for the research. A positive $\beta 2$ is expected

Trade openness captures trade restrictions. When trade restriction is reduced, it will attract more FDI (Aliyu, 2010). (+) gross fixed capital formation GDP
In a high inflationary period, firms face uncertainty in terms of product and input pricing, thus investors may limit the number of resources invested in such economies (Sneider \& Frey, 1985). (-)

is theoretically expected to have a positive impact on the economy. Thus, an increase in capital formation results in the growth of real GDP per capita, holding all other factors constant. As a result, the coefficient of capital is expected to be positive (Alagidede \& Ibrahim, 2017; Appiah-Konadu et al., 2016). The data was sourced from WDI.

7.Human Capital (HC)
Secondary School enrollment Population)
When the labour force is educated, productivity will be efficient which invariably can attract FDI, especially where labour cannot be exported (Kucera, 2002). (+) 


\subsection{Model Specification}

\subsubsection{Estimation of Exchange Rate Volatility}

To ascertain exchange rate volatility, there is the need to capture the value of the real exchange rate and it was captured on the assumption by Alagidede and Ibrahim (2017). The real exchange rate was used to capture the effect of inflation differentials to provide a robust measure of the price of foreign currency in real terms. It is modeled below as

$$
\operatorname{RER}=\operatorname{NER}\left(\frac{P x}{C P I}\right)
$$

where NER is the nominal exchange rate defined as the amount of GH $\varnothing$ needed to exchange US\$1; Px is the US price level proxied by the wholesale price index while CPI is the consumer price index reflecting domestic price levels. Thus, a rise (fall) in RER implies a real depreciation (real appreciation) of the Cedi.

Most studies used standard deviation to capture the exchange rate volatility (Engel \& Rose, 2000; Frankel \& Rose, 2002; Alesina, Barro, \& Tenreyro, 2002; Tenreyro 2007). This paper, therefore, agrees with Alagidede and Ibrahim (2017) and used Generalized Autoregressive Conditional heteroskedasticity (GARCH) which was developed by Bollerslev (1986). GARCH was used because the exchange rate follows GARCH processes and also capture past error term as compared to Autoregressive Conditional heteroskedasticity $(\mathrm{ARCH})$. The GARCH $(1,1)$ model is shown as;

$$
\begin{aligned}
& \operatorname{lnRER}=\alpha_{0}+\beta_{1} \operatorname{lnRER}_{t-1}+\varepsilon_{t} \\
& \sigma_{t}^{2}=\alpha_{0}+\gamma \mu_{t-1}^{2}+\beta \sigma_{t-1}^{2}
\end{aligned}
$$

Where, conditional variance of error term at time $\mathrm{t}\left(\sigma_{t}^{2}\right)$ depends on squared error term in the previous time $\left(\mu_{t-1}^{2}\right)$ and also on the previous lag of the conditional variance $\sigma_{t-1}^{2}$. The sum of $\alpha$ and $\beta$ measures the persistence of volatility. This means the GARCH model allows the error term to have a time-varying variance conditional on the past behaviour of the series hence reflecting the actual volatilities as perceived by agents. The exchange rate volatility $\left(\sigma_{t}^{2}\right)$ is represented by ERV.

\subsubsection{Growth Model}

From the Solow (1957) neo-classical production function with specialized advancement (authoritative upgrades that simply move the production function up through time), we can infer an articulation for the growth of total yield as a function of the growth of the information sources and the rate of specialized advancement. Most growth models indicated for creating nations depend on a neo-classical system. The model is worked around a steady returns production function that takes into consideration the chance of replacement among capital and labour.

$\mathrm{Y}=\mathrm{AF}(\mathrm{K}, \mathrm{L})$

Differentiating equation (4) with respect to time gives the following equation.

$d Y / d t=F(K, L) d A / d t+A \partial F / \partial K . d K / d t+A \partial F / \partial L \cdot d L / d t$

Dividing equation (5) by $\mathrm{Y}$ and simplifying gives

$$
\frac{d Y / d t}{Y}=\frac{F(K, L)}{\mathrm{AF}(\mathrm{K}, \mathrm{L})} \frac{d A}{d t}+\frac{A}{Y} \frac{d F}{d K} \frac{d K}{d t}+\frac{A}{Y} \frac{d F}{d L} \frac{d L}{d t}
$$


Multiply the second and third terms on the right-hand side of equation (6) respectively with $\mathrm{K} / \mathrm{K}$ and $\mathrm{L} / \mathrm{L}$ and simplify to get equation (4)

$$
\frac{d Y / d t}{Y}=\frac{d A}{A}+\frac{A K}{Y} \frac{d F}{d K} \frac{d K / d t}{K}+\frac{A L}{Y} \frac{d F}{d L} \frac{d L / d t}{L}
$$

The growth in output can be expressed as follows

$$
\mathrm{Y}=\mathrm{A}+\ni K+\vartheta L
$$

Where $\ni K=\frac{A K}{Y} \frac{d F}{d K}$ and $\vartheta L=\frac{A L}{Y} \frac{d F}{d L}$ are the output elasticities of capital and labour. Thus, equation (5) shows that the growth of capital stock, labour and the rate of technical progress explain the growth of aggregate output. Therefore, factors that are expected to increase capital stock, labour and the rate of technical progress will improve the growth of output in the long run. Endogenous growth models that have been developed allow growth in per capita output to be influenced by investment in human capital, physical capital, and research and development. Variables that affect accumulation or allocation of human and physical capital can be expected to affect growth (Chen \& Kee 2005).

The equation below represents the growth model;

Growth $_{t}=\beta_{0}+\beta_{1}$ Growth $_{t-1}+\beta_{2} F D I_{t}+\beta_{3} I N F_{t}+\beta_{4} T O_{t}+\beta_{6} H C_{t}+\beta_{7}$ Cap $_{t}+\varepsilon_{t}$

Where;

$\beta_{0}$ is the constant

$\beta_{1-7}$ is the coefficients

Growth $_{t}$ is Economic Growth

$F D I_{t}$ is the Foreign Direct Investment Inflows

Growth $_{t-1}$ is the lag of Economic Growth

Capital $_{t}$ is Domestic Capital

$I N F_{t}$ is the inflation rate

$\mathrm{TO}_{t}$ is Trade Openness

$H C_{t}$ is Human Capital

To capture the moderating role of exchange rate volatility, the economic growth model was specified as:

$$
\begin{aligned}
\text { Growth }_{t}=\beta_{0} & +\beta_{1} \text { Growth }_{t-1}+\beta_{2} F D I_{t}+\beta_{3} E R V_{t}+\beta_{4}\left(F D I_{t} \times E R V_{t}\right)+\beta_{5} I N F_{t}+\beta_{6} T O_{t}+\beta_{7} H C_{t} \\
& +\beta_{8} \operatorname{Cap}_{t}+\varepsilon_{t}
\end{aligned}
$$

Where;

$\beta_{0}$ is the constant

$\beta_{1-8}$ are the coefficients

Growth $_{t}$ is Economic Growth

$F D I_{t}$ is the Foreign Direct Investment Inflows

Growth $_{t-1}$ is the lag of Economic Growth

$E R V_{t}$ is the exchange rate volatility

$I N F_{t}$ is the inflation rate

$\mathrm{TO}_{t}$ is Trade Openness

$H C_{t}$ is Human Capital

$\left(F D I_{t} \times E R V_{t}\right)$ is the interaction term

Capital $_{t}$ is Domestic Capital 
To examine the net effect of FDI on growth, we partially differentiate Equation (10) for FDI, and this yields equation (11) below:

$\frac{\text { Growth }}{\partial F D I_{t}}=\beta_{2}+\beta_{4} E R V_{t}$

From equation (11), there are, four outcomes are possible: First, if both the coefficients of FDI $\left(\beta_{2}\right)$ and the interactive effect $\left(\beta_{4}\right)$ are negative, it means that FDI decreases economic growth and exchange rate volatility magnified the negative effect of FDI on growth. Second, if $\beta_{2}$ and $\beta_{4}$ are positive, then it implies that FDI increases growth, and exchange rate volatility magnify the positive effect of FDI on growth. Third, if $\beta_{2}$ is negative and $\beta_{4}$ is positive, then it implies that FDI decreases growth, and exchange rate volatility dampens the negative effect of FDI on growth. Finally, if $\beta_{2}$ is positive and $\beta_{4}$ is negative, then we conclude that FDI increases growth, and exchange rate volatility lowers the positive effect of FDI on growth.

\subsubsection{Estimation of Growth Model}

To examine the effect of foreign direct investment (FDI) on economic growth in Ghana: the moderating role of exchange rate volatility, the study used the Bound Test Method developed by Pesaran, Shin and Smith (1999) and additionally extended by Pesaran, Shin, and Smith (2001). This procedure is adopted because it is simple as opposed to other multivariate cointegration techniques such as the Johansen and Juselius (1990). The Bound Test allows the cointegration relationship to be estimated by OLS once the lag order of the model is identified.

Autoregressive Distributed Lag (ARDL) was used, and for ARDL to be used, then the dependent variable should be a function of the independent variables and past values of the dependent variable. This study uses annual time series data, a lag of the dependent variable was added to the function. ARDL is specified as;

$\Delta \operatorname{Ln} Y_{t}=\alpha+\sum_{j=1}^{k} \Delta \Phi \operatorname{Ln} Y_{t-j}+\sum_{j=1}^{p} \Delta \beta^{\prime} \operatorname{Ln} X_{t-j}^{\prime}+\varepsilon_{j t}$

$a=$ Intercept $\quad \varepsilon_{j t}=$ vector of Error term or unobserved variables

$X^{\prime}{ }_{t}=$ vector of independent variables which can either be I (0), I (1) or cointegrated

$\varphi, \beta=$ Coefficients

$Y^{\prime}{ }_{t}=$ vector of a dependent variable

$K=$ is the optimal lags used for the dependent variable

$P=$ is the optimal lags for exogenous variables

The method by Pesaran et al. (2001) necessitates the use of an Autoregressive Distributed Lag (ARDL) model to specify an Error Correction Model (ECM).

To estimate both long and short dynamics of this study, ARDL was specified as;

$$
\begin{aligned}
\Delta \text { Growth }_{t}=\beta_{0} & +\beta_{1} \Delta \text { Growth }_{t-1}+\sum_{j=0}^{k_{1}} \beta_{2, j} \Delta F D I_{t-j}+\sum_{j=0}^{k_{2}} \beta_{3, j} \Delta E R V_{t-j} \\
& +\sum_{j=0}^{k_{3}} \beta_{4, j}\left(\Delta F D I_{t-j} \times \Delta E R V_{t-j}\right)+\sum_{j=0}^{k_{4}} \beta_{5, j} \Delta I N F_{t-j}+\sum_{j=0}^{k_{5}} \beta_{6, j} \Delta T O_{t-j}+\sum_{j=0}^{k_{6}} \beta_{7, j} \Delta H C_{t-j} \\
& +\sum_{j=0}^{k_{7}} \beta_{8, j} \Delta \operatorname{Cap}_{t-j}+\beta_{9} E C T_{t-1}+\varepsilon_{t}
\end{aligned}
$$


Where;

$\beta_{0}$ is the constant, $\Delta$ is the difference operator

$\beta_{1-8}$ are the coefficients

$k_{1-7}$ are the optimal lags for the predictors

$P=$ is the optimal lags for exogenous variables

$\varepsilon_{t}=$ vector of Error term or unobserved variables

Growth $_{t}$ is Economic Growth

$F D I_{t}$ is the Foreign Direct Investment Inflows

Growth $_{t-1}$ is the lag of Economic Growth

$E R V_{t}$ is the exchange rate volatility

$I N F_{t}$ is the inflation rate

$\mathrm{TO}_{t}$ is Trade Openness

$H C_{t}$ is Human Capital

$\left(F D I_{t} \times E R V_{t}\right)$ is the interaction term

Capital $_{t}$ is Domestic Capital.

\section{Results and Discussions}

\subsection{Descriptive and Correlation Analysis}

Table 4.1 shows that Foreign Direct Investment, Human capital, Inflation, and Real exchange rate are skewed to the right while Growth and trade openness are skewed to the left. The maximum level of FDI which has been received by Ghana is $9.52 \%$ whereas the minimum amount of FDI received is $0.045 \%$ but on average, $2.96 \%$ of FDI as a percentage of GDP has been received as shown in Table 4.1. Furthermore, the highest growth in Ghana is $11.32 \%$ whereas the lowest growth in Ghana $-9.54 \%$ and the average is $1.88 \%$. Also, the maximum level of human capital obtained in Ghana $71.32 \%$ while the minimum level of human capital obtained in Ghana $30.03 \%$ and the average is $43.34 \%$.

Table 4.1: Descriptive Statistics

\begin{tabular}{lcrcrrr}
\hline \hline & FDI & GROWTH & HC & INF & \multicolumn{1}{c}{ RER } & \multicolumn{1}{c}{ TO } \\
\hline Mean & 2.958537 & 1.876977 & 43.34233 & 27.02766 & 0.149989 & 62.68761 \\
Median & 1.730357 & 1.973729 & 36.31826 & 18.03144 & 0.118256 & 65.92144 \\
Maximum & 9.517043 & 11.31545 & 71.31969 & 122.8745 & 0.361739 & 116.0484 \\
Minimum & 0.045328 & -9.542406 & 30.03387 & 7.126350 & -0.018469 & 6.320343 \\
Std. Dev. & 2.952043 & 3.617422 & 12.32421 & 25.11008 & 0.097805 & 28.38216 \\
Skewness & 0.796221 & -0.904968 & 1.215281 & 2.678081 & 0.605089 & -0.282310 \\
Kurtosis & 2.323024 & 5.986197 & 3.002068 & 10.26726 & 2.520338 & 2.380915 \\
Jarque-Bera & 4.865528 & 19.81402 & 9.599911 & 132.4399 & 2.753734 & 1.140853 \\
Probability & 0.087794 & 0.000050 & 0.008230 & 0.000000 & 0.252368 & 0.565284 \\
Observations & 39 & 39 & 39 & 39 & 39 & 39 \\
\hline SOut:
\end{tabular}

Source: Field Data, 2020

Table 4.2 presents the correlation coefficients of growth and other variables including FDI, human capital, inflation, real exchange rate volatility, and trade openness. The results suggest that growth is positively and significantly correlated with all the variables except inflation which is negative but insignificant. 
Table 4.2: Correlation Analysis

\begin{tabular}{|c|c|c|c|c|c|c|}
\hline GROWTH & $\begin{array}{r}\text { GROWTH } \\
1.000000 \\
-----\end{array}$ & FDI & $\mathrm{HC}$ & INF & RER & TO \\
\hline FDI & $\begin{array}{r}0.490005 \\
0.0015\end{array}$ & $\begin{array}{c}1.000000 \\
-----\end{array}$ & & & & \\
\hline $\mathrm{HC}$ & $\begin{array}{r}0.351943 \\
0.0280\end{array}$ & $\begin{array}{r}0.731246 \\
0.0000\end{array}$ & $\begin{array}{r}1.000000 \\
----\end{array}$ & & & \\
\hline INF & $\begin{array}{r}-0.617575 \\
0.0000\end{array}$ & $\begin{array}{r}-0.421961 \\
0.0075\end{array}$ & $\begin{array}{r}-0.345959 \\
0.0310\end{array}$ & $\begin{array}{c}1.000000 \\
-----\end{array}$ & & \\
\hline RER & $\begin{array}{r}0.246520 \\
0.1303\end{array}$ & $\begin{array}{r}0.057673 \\
0.7273\end{array}$ & $\begin{array}{r}-0.051842 \\
0.7540\end{array}$ & $\begin{array}{r}-0.435109 \\
0.0056\end{array}$ & $\begin{array}{c}1.000000 \\
-----\end{array}$ & \\
\hline TO & $\begin{array}{r}0.537250 \\
0.0004 \\
\end{array}$ & $\begin{array}{r}0.446839 \\
0.0043 \\
\end{array}$ & $\begin{array}{r}0.227671 \\
0.1633 \\
\end{array}$ & $\begin{array}{r}-0.513192 \\
0.0008 \\
\end{array}$ & $\begin{array}{r}-0.021682 \\
0.8958 \\
\end{array}$ & $\begin{array}{r}1.000000 \\
-----\end{array}$ \\
\hline
\end{tabular}

Source: Field Data, 2020

\subsection{Estimation of Exchange Rate Volatility}

Table 4.3 shows the results of the estimation of exchange rate volatility using GARCH model. The robustness of the results is examined to ensure model adequacy. Table 4.3 shows the results from the conditional variable equation and it indicates that the mean $\mathrm{Y}_{0}$ from equation (2) is positive albeit insignificant. The previous forecast error term $(\mathrm{GARCH})$ is positive and significant at $5 \%$. Also, further results reveal that previous information about the exchange rate volatility as measured by the squared residual $\left(\mathrm{U}_{\mathrm{t}-1}^{2}\right)$ from the mean equation is negative and flatly insignificant at conventional levels. The sum of the coefficient on the lagged squared error and lagged conditional variance is very close to unity $(0.32$ $=1$ ). This implies that volatility shocks are highly persistent suggesting the presence of volatility clustering in the trend of exchange rate.

Changes in exchange rate shock are followed by large (small) changes over a longer period. Similar to most financial and economic time series variables, the exchange rate exhibits significant periods of high volatility followed by relatively more tranquil periods of low volatility. The conditional real exchange rate volatility is presented below with the hope of providing some insights on the degree of exchange rate risk at least over the sample period.

Table 4.3: Exchange Rate Volatility

\begin{tabular}{lllll}
\hline \hline Variable & Coefficient & Std. Error & z-Statistic & Prob. \\
\hline \hline C & 0.101382 & 0.028267 & 3.586609 & 0.0003 \\
RER(1) & 0.328542 & 0.148484 & 2.212642 & 0.0269 \\
& \multicolumn{2}{l}{ Variance Equation } & & \\
\multicolumn{2}{l}{} & & \\
C & 0.001221 & 0.002023 & 0.603622 & 0.5461 \\
RESID(-1)^2 & 0.154552 & 0.185870 & 0.831507 & 0.4057 \\
GARCH(-1) & 0.677041 & 0.296842 & 2.280814 & 0.0226 \\
& & & & \\
\hline \hline
\end{tabular}




\begin{tabular}{llll}
\hline \hline R-squared & 0.010174 & Mean dependent var & 0.151083 \\
Adjusted R-squared & -0.017321 & S.D. dependent var & 0.098875 \\
S.E. of regression & 0.099728 & Akaike info criterion & -1.654910 \\
Sum squared resid & 0.358045 & Schwarz criterion & -1.439438 \\
Log-likelihood & 36.44328 & Hannan-Quinn criteria. & -1.578246 \\
Durbin-Watson stat & 2.055645 & & \\
\hline
\end{tabular}

Source: Field Data, 2020

\subsection{Cointegration Test}

From Table 4.4 the F-statistic estimated for all the three equations is greater than the upper bounds, which means all of them were even significant at $1 \%$. The null hypothesis of no cointegration is rejected against alternatives for all three equations. This means that these variables are cointegrated. By implication, all the variables converge in the long run. Once there is cointegration, ARDL with ECM is estimated.

Table 4.4: Cointegration Test

\begin{tabular}{lcccccccc}
\hline Model & \multicolumn{2}{c}{ F- statistics (k) } & \multicolumn{2}{c}{$90 \%$} & \multicolumn{2}{c}{$95 \%$} & \multicolumn{2}{c}{$99 \%$} \\
\hline \hline & & & $1(0)$ & $1(1)$ & $1(0)$ & $1(1)$ & $1(0)$ & $1(1)$ \\
Interaction & 6.743 & $(7)$ & 2.03 & 3.13 & 2.32 & 3.50 & 2.96 & 4.26 \\
& & & & & & & & \\
FDI-Growth & 11.550 & $(5)$ & 2.26 & 3.35 & 2.62 & 3.79 & 3.41 & 4.68 \\
ERV- Growth & 11.978 & $(5)$ & 2.26 & 3.35 & 2.62 & 3.79 & 3.41 & 4.68 \\
\hline \hline
\end{tabular}

(K) is the number of predictors

Source: Field Study, 2020

\subsection{Effect of FDI on Economic Growth}

\subsubsection{Long Run Estimate of FDI-Economic Nexus with ECM}

Table 4.5 shows the convergence of the variables in the long-run and is statistically significant at a $5 \%$ significance level. The coefficient of the $\mathrm{ECM}_{\mathrm{t}-1}$ is equal to $(-0.72312)$ for the short-run model which shows that deviation from the short-run in economic growth is corrected by $73.2 \%$ each year in the longrun. The negative sign of the adjusted coefficient also confirms the existence of cointegration between the variables. The expectation of economic theory suggests that the coefficient of foreign direct investment (FDI) enhances the economy and this was achieved. From Table 4.5, we found that FDI has a positive significant impact on economic growth at 1 percent significance level. A one-unit increase in FDI will lead to an increase in GDP growth by 0.1504 units, average ceteris paribus. This could be as a result of FDI spill over, which transcend into economic growth (Dal-Bianco and Loan, 2017). This results is consistent with theory and other empirical findings by (Balasubramanyam, et al., 1996; Asheghian, 2004; Vu, et al., 2006; Dal-Bianco and Loan, 2017).

Nonetheless, the coefficient of gross fixed capital formation proxying capital stock is negative and statistically significant at a 5 percent significance level. With a coefficient of (- 0.2645), it means that a unit increase in the capital stock will cause economic growth in Ghana to fall by approximately 0.2645 in the long-run run. This suggest that when domestic capital increases, economic growth reduces. This is inconsistent with the neo-classical theory and the endogenous growth theory which states that domestic capital affect economic growth. This does not support the findings of Appiah-Konadu et al. (2016) which stated that, domestic capital has great influence on economic growth.

The coefficient of openness to trade was 0.07648 , which means that a unit increase in trade openness will result in a 0.07648-unit increment in GDP, all things being equal. International trade leads to specialization and broadens the productivity base of a nation. Thus, an increase in the productivity base of a country tends to boost economic growth. From Keynesian's principle, high net export (trade openness) increases national income which eventually increases growth in the economy. 
Table 4.5: Long Run Estimate of FDI-Economic Growth Nexus with ECM

\begin{tabular}{lllll}
\hline \hline Variable & Coefficient & Std. Error & t-Statistic & Prob. \\
\hline \hline ECT $(-1)$ & $-0.72312 * * *$ & .14354 & -5.04 & 0.000 \\
FDI & $.1504332 * * *$ & .03215 & 4.61 & 0.000 \\
INF & -.0307036 & .0369993 & -0.83 & 0.416 \\
HC & .0295174 & .0617052 & 0.48 & 0.637 \\
CAP & $-.2644578 * *$ & .1154561 & -2.29 & 0.032 \\
TO & $0.076483 * * *$ & .0245711 & 3.11 & 0.005 \\
\hline \hline
\end{tabular}

$*, * *, * * *$ are significant levels at $10 \%, 5 \%$ and $1 \%$

Source: Field Study, 2020

\subsubsection{Short Run Estimate of FDI-Economic Growth Nexus}

In Table 4.6, only inflation was seen to have a negative influence on economic growth and it is statistically significant at $5 \%(\mathrm{p}=0.026<0.05)$. The expected sign of this variable revealed that, in a high inflationary period, firms face uncertainty in terms of product and input pricing, and thus investors may limit the number of resources invested in such economies. The whole model (both short run and long) has a great predicting power of $79.07 \%$ and it is significant at $5 \%$. This means that $79.07 \%$ variation in the dependent variable (economic growth) can be explained by the variation in the dependent variables such as FDI, inflation, trade openness, human capital, the interaction term, and the domestic capital. The model is free of issues including the serial correlation, the heteroscedasticity, and normality as presented in the Table 4.6 above since all the test fails to reject the null hypothesis.

Table 4.6: Short Run Estimate of FDI-Economic Growth Nexus

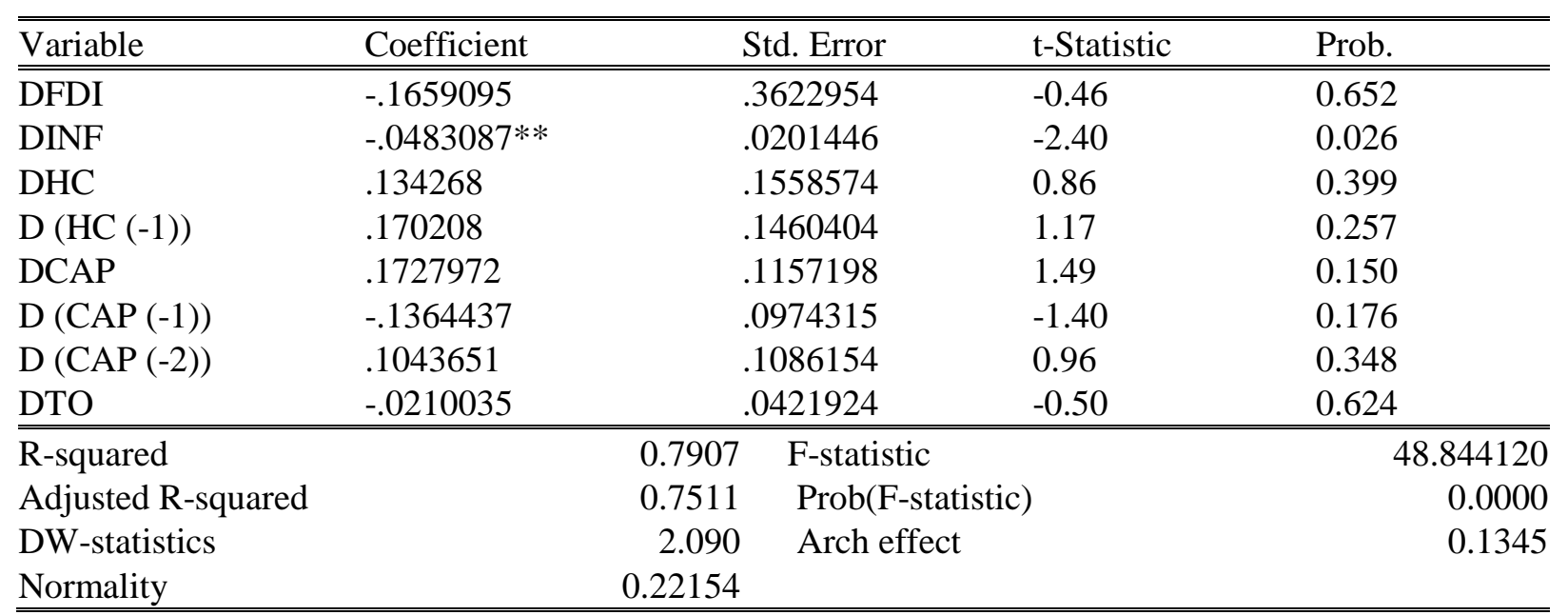

*,**,*** are significant levels at $10 \%, 5 \%$ and $1 \%$

Source: Field Study, 2020

\subsection{Effect of Exchange Rate Volatility on Economic Growth}

\subsubsection{Long Run of ERV- Economic Growth Nexus with ECM}

Table 4.7 showed that the coefficient of the lagged error correction term ECT (-1) exhibits the expected negative sign $(-0.2805)$ and is statistically significant at 1 percent. This indicates that $28.06 \%$ of the disequilibrium caused by previous years' shocks converges back to the long-run equilibrium in the current year. According to Kremers, Ericsson, and Dolado (1992) and Bahmani-Oskoe (2001), a relatively more efficient way of establishing cointegration is through the error correction term. Thus, the variables in the model reveal evidence of reasonable response to equilibrium when there is a shock in the short-run. The negative coefficient indicates that, whenever there is a disturbance in the short-run, it will be corrected in 
the long-run. The rule of thumb is that the greater the error correction coefficient (in absolute terms), the faster the variables adjust back to the long-run equilibrium when shocked (Acheampong, 2007). From the results, the coefficient of exchange rate volatility is statistically significant at 1 percent significance level, indicating that if the country were to experience exchange rate volatility by 1 percent, economic growth will decrease by approximately 9 percent in the long run. This suggests that volatility is deleterious to long-term growth. This confirms the study of Alagidede and Ibrahim (2017). From the results, the coefficient of trade openness is statistically significant at 1 percent significance level, indicating that, if the country were to increase her trade openness by 1 percent, economic growth will increase by 7.6 percent in the long run. According to economic theory, trade induces economic growth by enhancing capital formation and efficiency, and by increasing the supply of scarce resources. For Ghana, the results obtained suggest that the trade openness policy adopted as part of the structural reforms in 1980 in Ghana has affected growth positively. The results obtained in this study, in the long run, does not resolve the conflicting results in the extant literature but contribute to the controversy in the literature by aligning itself with those studies such as Edwards (1993); and, Nduka, et al (2013) which believe that trade openness positively affects GDP growth. However, Sachs and Warner (1995), and Hamad, et al (2014) found a negative impact of trade openness on economic growth.

The coefficient of the capital stock of 0.29 shows that a 1 percent increase in capital input would result in a 0.18 percent increase in real GDP, holding all other factors constant and is statistically significant at a 5 percent significance level. The sign of the capital variable supports the theoretical conclusion that capital contributes positively to the growth of output since the coefficient of capital in this long-run growth equation is positive and significant. The positive relationship between capital stock and output or economic growth is consistent with the expectation of the classical economic theory. The findings is in line with the findings of Shaheen, Ali, Kauser, and Bashir (2013); Falki (2009); Khan and Qayyum (2007); and consistent with conclusions reached by Aryeetey and Fosu (2003), and Asiedu (2013) in the case of Ghana.

Table 4.7: Long Run of ERV-Economic Growth Nexus with ECM

\begin{tabular}{lllll}
\hline \hline Variable & Coefficient & Std. Error & t-Statistic & Prob. \\
\hline \hline ECT $(-1)$ & $-0.2805^{* * *}$ & 0.058420 & -4.80 & 0.000 \\
ERV & $-0.0871^{* * *}$ & 0.016610 & -5.25 & 0.008 \\
INF & -0.0289 & 0.035015 & -0.82 & 0.419 \\
HC & 0.04969 & 0.058275 & 0.85 & 0.403 \\
CAP & $0.29108^{* *}$ & 0.128172 & 2.27 & 0.034 \\
TO & $0.07648 * * *$ & 0.024571 & 3.11 & 0.005 \\
\hline \hline
\end{tabular}

$*, * *, * * *$ are significant levels at $10 \%, 5 \%$ and $1 \%$

Source: Field Study, 2020

\subsubsection{Short Run Estimate of ERV-Economic Growth}

Table 4.8 showed that the whole model (both short run and long) has a great predicting power of $82.41 \%$ and it is significant at $5 \%$. This means that $82.41 \%$ variation in the dependent variable (economic growth) can be explained by the variation in the dependents variables such as exchange rate volatility, inflation, trade openness, human capital, the interaction term, and the domestic capital. Also, a DW-statistics of 2.0325 reveals that there is no first order autocorrelation in the residuals. Since the p-value $(0.125)$ is more than 5 percent $(\mathrm{p}>0.05)$, we fail to reject the null hypothesis of homoskedasticity meaning the output is not suffering from heteroskedasticity (the variance of expected error term condition on the independent variables is constant)

In the short run, inflation was significant at $5 \%$ with a negative coefficient of $4.34 \%$ suggesting that, as inflation increases all things being equal, the value of the economy will reduce by $4.34 \%$. 
Table 4.8: Short Run Estimate of ERV- Economic Growth

\begin{tabular}{lllll}
\hline \hline Variable & Coefficient & Std. Error & t-Statistic & Prob. \\
DERV & -377.87 & 475.3943 & -0.79 & 0.436 \\
DINF & $-.0434738^{* *}$ & .0206157 & -2.11 & 0.047 \\
D HC & .140924 & .137121 & 1.03 & 0.316 \\
D (HC (-1)) & .1786771 & .12736 & 1.40 & 0.175 \\
D CAP & .1540119 & .1239836 & 1.24 & 0.228 \\
D (CAP (-1)) & -.1462683 & .1047942 & -1.40 & 0.177 \\
D (CAP (-2)) & .0776974 & .1012769 & 0.77 & 0.452 \\
DTO & -.0245628 & .036102 & -0.68 & 0.504 \\
\hline R-squared & 0.8241 & F-statistic & 48.844120 \\
Adjusted R-squared & 0.7069 & Prob(F-statistic) & 0.0020 \\
DW-statistics & 2.0325 & Arch effect & \\
Normality & 0.32154 & \multicolumn{2}{l}{} \\
\hline \hline
\end{tabular}

*,**,*** are significant levels at $10 \%, 5 \%$ and $1 \%$

Source: Field Study, 2020

\subsection{The Moderating Role of ERV on FDI-Growth}

\subsubsection{Long-Run Effect of Interaction Term}

Table 4.9 showed the speed of adjustment from the short-run towards the long-run equilibrium. A highly significant ECM coefficient proves the existence of a long-run relationship. From the parsimonious estimate, the coefficient of the error correction term was $(0.23)$ and statistically significant as observed from Table 4.9. The coefficient estimates of the error correction term of 0.23 implied that the model corrects its short-run disequilibrium by 23 percent speed of adjustment to return to the long-run equilibrium.

A one percent increase in FDI will lead to a fall in GDP growth by 0.02 percent approximately, all other things remaining the same. This negative relationship between FDI and GDP growth in Ghana is consistent with a previous study by Frimpong and Oteng-Abayie (2006), and Mwinlaaru and Ofori (2017) but inconsistent with theory and other empirical findings by Balasubramanyam, et al. (1996), Asheghian (2004) and Vu, et al. (2006).

Table 4.9: Long Run of the Interaction Term

\begin{tabular}{lllll}
\hline \hline Variable & Coefficient & Std. Error & t-Statistic & Prob. \\
\hline \hline ECT $(-1)$ & $-0.231452^{* * *}$ & .2211482 & -3.20 & 0.008 \\
FDI & $-2.933945^{*}$ & 1.581263 & -1.86 & 0.088 \\
ERV & 122.2128 & 428.7557 & 0.29 & 0.780 \\
INF & .0721462 & .1034094 & 0.70 & 0.499 \\
HC & .4178956 & .345796 & 1.21 & 0.250 \\
CAP & -.1971231 & .4004588 & -0.49 & 0.631 \\
TO & .1474067 & .0922369 & 1.60 & 0.136 \\
$\quad(F D I \times E R V)$ & $0.86125^{* * *}$ & 0.15231 & 5.65 & 0.000 \\
\hline \hline
\end{tabular}

*,**,*** are significant levels at $10 \%, 5 \%$ and $1 \%$

Source: Field Study, 2020

\subsubsection{Short Run of the Interaction Term}

Table 4.10 shows that, the inclusion of the interaction term has caused an increase in the R-squared as compared to the two-models discussed early, suggesting that the exchange rate volatility has a great impact on the effect of foreign direct investment on economic growth. The R-squared has a coefficient of 
$82.07 \%$ which is $1 \%$ significant implying that the explanatory variables have explained economic growth by $82.07 \%$. The coefficients of the post estimation show that the result is robust and therefore policymakers can depend on it to make relevant decisions using data set ranging from 1980-2018.

FDI was seen to have a positive significant impact on economic growth in the short run having a coefficient of 2.603 implying that a unit increase in FDI inflows will lead to an increase in the economic growth by 2.603 units. The result, however, is not supported by the result obtained in the long run. This confirms the study by Sethi (2013) which stated that foreign capital may impact economic growth in the short-run but not in the long run, FDI deteriorates economically through factors such as capital flight, corruption, and others. The partial differentiation suggested that if $\beta_{2}$ is positive and $\beta_{4}$ is negative, then we conclude that FDI increases growth, and exchange rate volatility lowers the positive effect of the FDI on growth. This implies that in the presence of exchange rate volatility, the effect of FDI on economic growth is very minimal.

Table 4.10: Short Run of the Interaction Term

\begin{tabular}{|c|c|c|c|c|}
\hline Variable & Coefficient & Std. Error & t-Statistic & Prob. \\
\hline DFDI & 2.603443 & .804768 & 3.24 & 0.007 \\
\hline DERV & 262.1244 & 360.1169 & 0.73 & 0.481 \\
\hline DINF & -.1031153 & .0336961 & -3.06 & 0.010 \\
\hline $\mathrm{DHC}$ & -.3647044 & .1914846 & -1.90 & 0.081 \\
\hline DHC (-1) & -.1740278 & .1538969 & -1.13 & 0.280 \\
\hline DCAP & .0993202 & .2170279 & 0.46 & 0.655 \\
\hline $\mathrm{D}(\mathrm{CAP}(-1))$ & -.2381553 & .188795 & -1.26 & 0.231 \\
\hline $\mathrm{D}(\mathrm{CAP}(-2))$ & .1083657 & .1734884 & 0.62 & 0.544 \\
\hline DTO & -.0656781 & .0360556 & -1.82 & 0.094 \\
\hline$D(F D I x E R V)$ & -159.0593 & 64.55846 & -2.46 & 0.030 \\
\hline $\mathrm{R}$-squared & \multicolumn{3}{|c|}{ F-statistic } & 48.844120 \\
\hline Adjusted R-squared & & $0.7011 \quad$ Prob & Prob (F-statistic) & 0.0000 \\
\hline DW-statistics & & 2.105 & Arch effect & 0.2245 \\
\hline Normality & & 0.62154 & & \\
\hline
\end{tabular}

*,**, $* * *$ are significant levels at $10 \%, 5 \%$ and $1 \%$

Source: Field Study, 2020

In summary, the study found that FDI had a positively significant impact on economic growth in the short run whereas exchange rate volatility had a negatively significant impact over the long run. Again, domestic capital and trade openness had a positively significant impact on economic growth in the long run. Furthermore, looking at the interaction term between FDI and exchange rate volatility, it was discovered that the long run results was staggering and in contravention with expectation as economic theory suggested. The overall estimate suggests that over the short run FDI will increase economic growth and exchange rate volatility will reduce the positive effect of FDI on economic growth.

\section{Conclusion}

The main objective of the study was to examine the effect of foreign direct investment on economic growth in Ghana: the moderating role of exchange rate volatility both in the short run and the long run. The long-run estimate suggests that FDI will decrease growth and exchange rate volatility will dampen the negative effect of FDI on growth. In the short run, FDI affects positively the economic growth while the presence of exchange rate volatility shows that the effect of FDI on economic growth is reduced significantly. A volatile exchange rate could raise strategic and managerial issues because it could lead to 
exchange rate losses or gains. This may create uncertainties for investors to invest in the market. The volatile nature of the exchange rate market in the country also means that firms that import raw materials or market their products internationally need to make use of forward contracts in other to hedge their payables and receipts. It is also recommended that investors would take into consideration the nature of volatility in the exchange rate market and other macroeconomic variables in the economy to make an informed decision as to where to direct their investments to maximize their returns.

\section{References}

Acheampong, I.K. (2007). Testing Mckinnon-Shaw Thesis in the Context of Ghana's Financial Sector Liberalisation Episode. International Journal of Management Research and Technology, 1 (2), 156183.

Adams, S. \& Opoku, E.E.O. (2015). Foreign Direct Investment, Regulations and Growth in sub-Saharan Africa. Economic Analysis and Policy, 47, 48-56.

Adenutsi, D.E. (2008). Effect of Trade Openness and Foreign Direct Investment on Industry Performance in Ghana. Journal of Business Research (JBR), 2, 1-2.

Agri, E.M., Felix, N.D., Iyaji, E.A. Rosemary, A. \& Vonke, D. (2018). Effect of Exchange Rate Policy and its Volatility on Economic Growth in Nigeria. International Journal of Advanced Studies in Economics and Public Sector Management, 6 (2), 166-190.

Alagidede, P., \& Ibrahim, M. (2017). On the Causes and Effects of Exchange Rate Volatility on Economic Growth: Evidence from Ghana. Journal of African Business, 18(2), 169-193. https://doi.org/10.1080/15228916.2017.1247330

Alagidede, P., Baah-Boateng, W., \& Nketiah-Amponsah, E. (2013). The Ghanaian Economy: An Overview. Ghanaian Journal of Economics, 1(1), 4-34.

Ali, W. \& Abdullah, A. (2015). The Impact of Trade Openness on the Economic Growth of Pakistan: 1980-2010. Global Business and Management Research: An International Journal, 7 (2), 120-129.

Aliyu, S. U. R. (2010). Exchange rate volatility and export trade in Nigeria: An empirical investigation. Applied Financial Economics, 20(13), 1071-1084. https://doi.org/10.1080/09603101003724380

Antwi S., Mills. E. F. E. A., Mills G. A., Zhao X. (2013). Impact of Foreign Direct Investment on Economic Growth: Empirical Evidence from Ghana. International Journal of Academic Research in Accounting, Finance and Management Sciences, 3 (1), 18-25.

Antwi, S., \& Koranteng, E. O. (2017). International Remittances and Economic Growth in Ghana; Does the Measure of Financial Development Matter? International Journal of Technology and Management, 2(1), 46-59.

Appiah-Konadu, P., Shitsi, F. J., Abokyi, E., \& Twerefou, D. K. (2016). The Effect of Foreign Aid on Economic Growth in Ghana. African Journal of Economic Review, 5(2), 248-261.

Asheghian, P. (2004). Determinants of Economic Growth in the United States: The Role of Foreign Direct Investment. The International Trade Journal, 18 (1), 63-83.

Asiedu, M.K. (2013). Trade Liberalization and Growth: The Ghanaian Experience. Journal of Economics and Sustainable Development, 4 (5), 125-135.

Bahmani-Oskooee, M. and Hajilee, M. (2013). Exchange Rate Volatility and its Impact on Domestic Investment. Research in Economics, 67, 1-12.

Balasubramanyam, V.N., Salisu, M. \& Sapsford, D, (1996). Foreign Direct Investment and Growth in EP and IS countries. The Economic Journal, 106, 92-105.

Banerjee, A., Dolado, J. \& Mestre, R. (1998). Error-Correction Mechanism Tests for Cointegration in a Single-Equation Framework. Journal of Time Series Analysis, 19 (3), 267-283.

Bollerslev, T. (1986). Generalised Autoregressive Conditional Heteroscedasticity. Journal of Econometrics, 31 (3), 307-327. doi: 10.1016/0304-4076(86)90063-1

Brook, C. (2014). Modeling long-run relationships in finance. In Introductory Econometrics for Finance (2nd Edition ed., pp. 318-365). New York: Cambridge University Press. 
Colombage, S. R., \& Halabi, A. K. (2012). Asymmetry of information and the finance-growth nexus in emerging markets: empirical evidence using panel VECM analysis. The Journal of Developing Areas, 46(1).

Dal Bianco, S., \& Loan, N. (2017). FDI Inflows, Price, and Exchange Rate Volatility: New Empirical Evidence from Latin America. International Journal of Financial Studies, 5(6), 1-17.

Dickey, D. A. and Fuller, W. A. (1979). Distribution of the Estimators for Autoregressive Time Series with a Unit-root. Journal of the American Statistical Association, 74: 427-431.

Edwards, S. (1993). Openness, Trade Liberalization and Growth in Developing Countries. Journal of Economics Literature, 31 (2), 1358-1393.

Engel, C. \& Rose, A. (2000). Currency Unions and International Integration. Journal of Money, Credit and Banking, 136, 381-400.

Evans, Y., Kesse, C., Gladys, A. \& Nyamoto, K.K. (2018). Foreign Direct Investment Inflows in Ghana: Is There Any Political and Priority Influence in the Distribution among the Sectors and Regions of the Ghanaian Economy? Open Journal of Business and Management, 6, 973-989.

Falki, N. (2009). Impact of Foreign Direct Investment on Economic Growth in Pakistan. International Review of Business Research Papers, 5 (5), 110-120.

Fambon, S. (2013). Foreign capital inflow and economic growth in Cameroon. World Institute for Development Economics Research, 1-22.

Frankel, J. and Rose, A. (2002). An Estimate of the Effect of Common Currencies on Trade and Income. Quarterly Journal of Economics, 117(2), 437-466.

Frimpong, J. M., \& Oteng-Abayie, E. F. (2006). Bivariate Causality Analysis between FDI Inflows and Economic Growth in Ghana. Retrieved from https://mpra.ub.uni-muenchen.de/351/.

Gertler and K. Rogoff (ed.), NBER Macroeconomics Annual. NBER Working Paper No. 9072.

Githanga, B.W. (2015). Trade Liberalization and Economic Growth in Kenya: An Empirical Investigation (1975-2013). Master Thesis, Department of Economics, Södertörns högskola.

Hamad, M. M., Mtengwa, B. A., \& Babiker, S. A. (2014). The Impact of Trade Liberalization on Economic Growth in Tanzania. International Journal of Academic Research in Business and Social Sciences, 4 (5), 514.

Johansen, S., \& Juselius, K. (1990). Maximum Likelihood Estimation and Inference on Cointegration with Application to the Demand for Money. Oxford Bulletin of Economics and Statistics, 52 (2), 169-210.

Khan, M. A., \& Qayyum, A. (2007). Trade, Financial and Growth Nexus in Pakistan. Economic Analysis Working Papers.

Kiliçarslan, Z. (2018). The Relationship between Exchange Rate Volatility and Foreign Direct Investment in Turkey: Toda and Yamamoto Causality Analysis. International Journal of Economics and Financial Issues, 8(4), 61-67.

Kremers, J. J., Ericsson, N. R., \& Dolado, J. J. (1992). The Power of Cointegration Tests. Oxford Bulletin of Economics and Statistics, 54 (3), 325-348.

Kucera, D. (2002). Core Labour Standards and Foreign Direct Investment. International Labour Review, $141(1 / 2), 31-69$.

Kyereboah-Coleman, A. and Agyire-Tettey, K.F. (2008) Effect of Exchange-Rate Volatility on Foreign Direct Investment in Sub-Saharan Africa: The Case of Ghana. The Journal of Risk Finance, 9 (1), $52-70$

Mmieh, F. \& Owusu-Frimpong, N. (2004). State policies and the challenges in attracting foreign direct investment: a review of the Ghana experience. Thunderbird International Business Review, 46 (5), $575-599$.

Mwinlaaru, P.Y. \& Ofori, I.K. (2017). Real Exchange Rate and Economic Growth in Ghana. MPRA Paper No. 82405. https://mpra.ub.uni-muenchen.de/82405/

Narayan, P. K. (2005). The Saving and Investment Nexus for China: Evidence from Cointegration Tests. Applied Economics, 37, 1979-1990.

Narayan, P.K. \& Narayan, S. (2006). Savings Behaviour in Fiji: An Empirical Assessment using the 
ARDL Approach to Cointegration. International Journal of Social Economics, 33, 468-480.

Nduka, E.K., Chukwu, J.O. Kalu, I. K \& Nwakaire, O.N. (2013). Trade Openness and Economic Growth: A Comparative Analysis of the Pre and Post Structural Adjustment Programme (Sap) Periods in Nigeria. Asian Journal of Business and Economics, 3 (3), 1-12.

Nketsiah, I. \& Quaidoo, M. (2017). The Effect of Foreign Direct Investment on Economic Growth in Ghana. Journal of Business and Economic Development, 2 (4), 227-232.

Nyarko, P. A., Nketiah-Amponsah, E., \& Barnor, C. (2011). Effects of Exchange Rate Regimes on FDI Inflows in Ghana. International Journal of Economics and Finance, 3 (3), 277-286.

Obeng, C. K. (2014). Effect of corporate tax on sector-specific foreign direct investment in Ghana. Munich Personal RePEc Archive, 58454.

Pesaran, M. H., Shin, Y. \& Smith, R. J. (2001). Bounds Testing Approaches to the Analysis of Level Relationships. Journal of Applied Econometrics, 16, 289-326.

Pesaran, M. H., Shin, Y., \& Smith, R. P. (1999). Pooled Mean Group Estimation of Dynamic Heterogeneous Panels. Journal of the American Statistical Association, 94 (446), 621-634.

Phillips, P. C. B. \& Perron, P. (1988). Testing for a Unit Root in Time Series Regression. Biometrika,75 (2), 335-346.

Raj, T. \& Pahwa, A. (2018). Impact of Foreign Investments on Economic Growth of India. Research Review International Journal of Multidisciplinary, 3 (12), 53-57.

Sachs, J.D. and Warner, A. (1995). Economic Reform and the Process of Global Integration. Brookings Papers on Economic Activity, 26, 1-118.

Schneider, F. \& Frey, B. S. (1985). Economic and Political Determinants of Foreign Direct Investment. World Development, 13, 161-175.

Sethi, N. (2013). Causal Relationship between Foreign Capital Inflows and Economic Growth: Empirical Evidence from India. International Journal of Economics, Finance, and Management, 2(1), 65-69.

Shaheen, S., Ali, M. M., Kauser, A., \& Bashir, F. (2013). Impact of Trade Liberalization on Economic Growth in Pakistan. Interdisciplinary Journal of Contemporary Research in Business, 5 (5).

Sokang, K. (2018). The Impact of Foreign Direct Investment on Economic Growth in Cambodia: Empirical Evidence. International Journal of Innovation and Economic Development, 4 (5), 31-38. https://doi.org/10.18775/ijied.1849-7551-7020.2015.45.2003

Solow, R.M. (1957). Technical Chane and the Aggregate Production Function. The Review of Economics and Statistics, 39 (3), 311-320.

Tenreyro, S. (2007). On the Trade Impact of Nominal Exchange Rate Volatility. Journal of Development Economics, 82 (2), 485-508.

Tuffour, J. K. (2013). Foreign Aid, Domestic Revenue, and Economic Growth in Ghana. Journal of Economics and Sustainable Development, 25-33.

Tweneboah, G., \& Alagidede, P. (2015). Dollarization in Ghana: Measurements, determinants and policy implications (Working Paper No. 315). African Finance and Economics Consult.

Ullah, S., Haider, S. Z., \& Azim, P. (2012). Impact Of Exchange Rate Volatility On Foreign Direct Investment: A Case Study of Pakistan. Pakistan Economic and Social Review, 50 (2), 121-138.

Vu, T.B., Gangnes, B., and Noy, I. (2006). Is Foreign Investment Good for Growth? Answers Using Sectoral Data from China and Vietnam. Unpublished.

Wijeweera, A., Villano, R., \& Dollery, B. (2010). Economic Growth and FDI Inflows: A Stochastic Frontier Analysis. The Journal of Developing Areas, 43 (2), 143-158.

World Bank (2019). World Development Indicators. Retrieved from The World Bank: www. databank.worldbank.org

World Bank. (2013). World Development Indicators. Washington D.C: World Bank. 